DIAS-ARIEIRA CR; MATTEI D; PUERARI HH; RIBEIRO RCF. 2015. Use of organic amendments in the management of root-knot nematode in lettuce. Horticultura Brasileira 33: 488-492. DOI - http://dx.doi.org/10.1590/S0102-053620150000400013

\title{
Use of organic amendments in the management of root-knot nematode in lettuce
}

\author{
Claudia R Dias-Arieira ${ }^{1}$; Danielle Mattei ${ }^{1}$; Heriksen H Puerari'; Regina CF Ribeiro² \\ ${ }^{1}$ Universidade Estadual de Maringá (UEM), Maringá-PR, Brasil; crdarieira@uem.br; dani.mattei@hotmail.com; heriksenhp@hotmail. \\ com; ${ }^{2}$ Universidade Estadual de Montes Claros, Janaúba-MG, Brasil; recafe@yahoo.com.br
}

\begin{abstract}
Root-knot nematodes, Meloidogyne spp., are among the most important parasites of the lettuce crop. Managing these organisms is difficult due to limitations in genetic (use of resistant cultivars) and chemical control. Thus, new practices should be sought to reduce their reproduction. The present study aimed to evaluate the application of organic amendments in the control of Meloidogyne incognita in lettuce. At first, tomato plants were inoculated to establish an initial population in the soil. After 60 days, the aerial part was discarded, and the lettuce seedlings were transplanted into pots. Two days after transplanting, the treatments bokashi, crambe cake, whey protein, cottonseed composted and shredded wood chip composted were applied at $20 \mathrm{~g}$ or $20 \mathrm{~mL}$ per pot. Water was applied as control treatment. After 70 days, bokashi and crambe meal reduced the number of eggs/g of root and promoted plant growth. Results obtained with whey protein, cottonseed meal and composted shredded wood chip did not differ from those obtained with the control treatment. Bokashi and crambe cake are effective in the M. incognita control under controlled conditions.
\end{abstract}

Keywords: Meloidogyne incognita, composted waste, bokashi, leftover cake, whey protein.

\section{RESUMO}

Uso de matéria orgânica no manejo de nematoide das galhas em alface

Os nematoides das galhas, Meloidogyne spp., estão entre os mais importantes parasitos da cultura da alface. O manejo destes organismos é difícil, pelas limitações que o controle genético (uso de cultivares resistentes) e químico apresenta, sendo necessária a busca por práticas alternativas para redução da reprodução. Assim, objetivou-se avaliar a aplicação de diferentes materiais orgânicos no controle de Meloidogyne incognita em alface. Inicialmente o nematoide foi inoculado em tomateiro para o estabelecimento de uma população inicial no solo. Após 60 dias descartou-se a parte aérea, transplantando as plântulas de alface para os vasos. Dois dias após o transplante, aplicaram-se os tratamentos bokashi, torta de crambe, soro de leite, compostado de caroço de algodão e compostado de madeira de poda triturada, usando $20 \mathrm{~g}$ ou $20 \mathrm{~mL}$ por vaso. A água foi utilizada como testemunha. Após 70 dias observou-se que os tratamentos bokashi e torta de crambe reduziram o número de galhas/g de raiz e de ovos/g de raiz e promoveram o desenvolvimento da planta. Os tratamentos com soro de leite, compostado de caroço de algodão e compostado de madeira de poda triturada não diferiram da testemunha. Pode-se concluir que bokashi e torta de crambe são eficientes para o controle de $M$. incognita em condições controladas.

Palavras-chave: Meloidogyne incognita, compostados orgânicos, bokashi, tortas vegetais, soro de leite.

(Recebido para publicação em 18 de abril de 2014; aceito em 28 de abril de 2015) (Received on April 18, 2014; accepted on April 28, 2015)

\section{L} ettuce (Lactuca sativa) is one of the most widely grown leafy vegetables, with China supplying $50 \%$ of the lettuce grown worldwide, followed by the United States and the European Union (FAO, 2005). Brazil produces 525,602 tons of lettuce, which corresponds to $11 \%$ of the national production of vegetables (HortiBrasil, 2013).

The occurrence of plant diseases can limit the productivity of this crop, especially root-knot nematodes, to which many cultivars are susceptible (Fiorini et al., 2007; Dias-Arieira et al., 2012). In regions with high temperatures, the species Meloidogyne incognita and $M$. javanica are the most destructive (Fiorini et al., 2007), and may cause $100 \%$ loss in production, depending on the infestation level and the cultivar used (Charchar, 1995).

In the field, these nematodes have high reproductive rates, which increase the population density of the pathogen in the soil. The main observed sign is the presence of galls on the roots, which become shorter and with few side roots. In the aerial part, the plants are yellowish, stunted, smaller, lighter and withered lettuce heads may be seen (Pinheiro et al., 2013).

After the establishment of a population of nematodes in a given area, eradication is impossible, and the adoption of integrated management actions is required. The use of chemical control has limitations to vegetables, especially the toxicity of products and lack of registration for lettuce and other plants in Brazil (Charchar, 1995).

The use of resistant cultivars is the most desirable method to reduce the nematode population, particularly because of absent risk to the producer 
and to the environment. Therefore, the search for resistant cultivars to Meloidogyne spp. is continuous (Fiorini et al., 2007; Silva et al., 2008; Ferreira et al., 2011). The curled-leaved cultivars have been cited as more tolerant to root-knot nematodes (Fiorini et al., 2005). However, the number of resistant and adapted genotypes to the different cultivation regions is limited.

Alternative methods, such as crop rotation, have been suggested for the management of these parasites on lettuce, including the cultivation of nematode antagonists (Moraes et al., 2006; Santana et al., 2012) which, besides reducing the population of nematodes, promote the improvement of physical, chemical and biological properties of the soil (Charchar et al., 2009). However, this control method is not always accepted by the producer, who often cannot afford to keep areas uncultivated for periods of 60 to 90 days.

Therefore, searching for other management alternative is important, and the use of organic amendments provides many benefits, such as the increase in the population of natural enemies (Oka, 2010), changes in physical and chemical properties of soil, including base saturation, porosity and conductivity of water, which leads to better plant growth and greater tolerance to pathogens (Akhtar \& Malik, 2000; González et al., 2010). Despite the positive results of the research involving the use of organic amendments in the control of nematodes (Lopes et al., 2008; Roldi et al., 2013), some sources have not been fully assessed. Thus, we aimed to assess the effectiveness of organic amendments in the control of M. incognita in lettuce.

\section{MATERIAL AND METHODS}

The experiment was conducted at Universidade Estadual de Maringá, Paraná State, Brazil, in entirely randomized design, with five replications, in two different environments, from April to August, 2012. Experiment 1 was carried out in the greenhouse, at temperatures ranging from 21.0 to $28.0^{\circ} \mathrm{C}$, while in experiment 2 the area was covered with a mesh, and temperatures ranged from 16.3 to $26.0^{\circ} \mathrm{C}$.

Tomato cultivar Santa Clara seedlings, produced in polystyrene trays using Plantmax ${ }^{\circledR}$ substrate, were transplanted, after 15 days of germination, to 2 liter plant pots, containing a mixture soil:sand (2:1, $\mathrm{v}: \mathrm{v})$, previously autoclaved at $120^{\circ} \mathrm{C}$ for $2 \mathrm{~h}$. After the second pair of leaves was fully expanded, seedlings were inoculated with 5,000 eggs and secondstage juveniles (J2) of $M$. incognita. The inoculum was obtained from a pure nematode population kept on roots of tomato plants, cultivar Santa Clara. The inoculum was extracted according to the method proposed by Hussey \& Barker (1973), adapted by Boneti \& Ferraz (1981). The suspension was calibrated for 1,000 eggs and $\mathrm{J} 2 / \mathrm{mL}$.

After 70 days of cultivation, the aerial part was discarded and the soil was superficially revolved. Subsequently, the lettuce cultivar Vera, produced on trays, as previously described for the cv. Santa Clara, was planted in each pot. Two days after transplant, the treatments were applied, which consisted of bokashi, crambe cake, whey protein, cottonseed composted and shredded wood chip composted. The treatment with water was used as control. The treatments were applied at the superficial soil layer (5 $\mathrm{cm}$ depth), at the concentration of $20 \mathrm{~g} / \mathrm{pot}$, except for whey protein and water, which were applied at a concentration of $20 \mathrm{~mL} /$ pot.

The bokashi used in the study was commercially produced by Nutri Bokashi $\left(\right.$ Korin $\left.^{\circledR}\right)$; the crambe cake, byproduct of the extraction of oil from the seeds of Crambe abysinica (Brassicaceae) using mechanical press, was donated by RM Indústria (Campo Grande, Mato Grosso do Sul); the whey protein was donated by Umuleite (Umuarama, Paraná) and the composted waste was obtained by grinding the material, making piles and fermentation for approximately 90 days.

Sixty days after application of the organic amendments, vegetative variables were assessed (mass of aerial part and fresh roots), and nematological variables \{total number of galls and eggs/g of roots (obtained by the total number of nematode divided by the root mass)\}. The eggs were extracted according to the method previously cited and evaluated in Peter's plate under an optical microscope.

The data obtained were subjected to analysis of variance, and the average values compared by Tukey test at 5\% probability. For analysis, the original data were transformed by $\sqrt{x+1}$.

\section{RESULTS AND DISCUSSION}

The highest values of total number of galls were obtained for the treatment with bokashi (experiment 1) and crambe cake (experiment 2) (Table 1). However, assessment of the number of galls/g of roots showed no statistical difference between the treatments in experiment 1 , while in experiment 2 , the lowest values were obtained in the treatments with bokashi and crambe cake (Table 1).

The number of eggs/g of roots was significantly lower in the treatments with bokashi and crambe cake compared to the control, in both experiments. Although whey protein was as effective as crambe cake, it did not differ from the control treatment and was less effective than bokashi (Table 1).

The bokashi, organic compound originated from the fermentation of the meals, reduced the number of eggs of $M$. incognita in 96.9 and $98.9 \%$ in experiments 1 and 2, respectively, compared to the control. Roldi et al. (2013) have previously found that the egg number of $M$. incognita in tomato plants was reduced from 4517.8 to 353.6 and from 5857.8 to 251.4 when bokashi was applied to soil in the concentration of $20 \mathrm{~g}$ per pot (2 liter pots). The organic compounds of bokashi, especially castor bean, would be responsible for the effect of the product on nematodes (Roldi et al., 2013), since castor bean had effectively reduced nematodes in other studies (Lopes et al., 2009).

The crambe cake was one of the organic amendment sources that promoted the greatest reduction in nematode eggs number compared to the control treatment, with a decrease of 94.3 and $97.2 \%$ in experiments 1 and 2 , respectively, corroborating several 
Table 1. Number of galls and eggs of Meloidogyne incognita per gram of lettuce roots after 60 days of cultivation in two experiments under different environmental conditions (número de galhas e de ovos de Meloidogyne incognita por grama de raizes de alface após 60 dias de cultivo em dois experimentos mantidos em diferentes condições ambientais). Umuarama, UEM, 2012.

\begin{tabular}{lcccccccc}
\hline \multirow{2}{*}{ Treatment } & \multicolumn{2}{c}{ Galls } & & \multicolumn{2}{c}{ Gall/g roots } & & \multicolumn{2}{c}{ Eggs/g roots } \\
\cline { 2 - 3 } \cline { 8 - 9 } & Exp. 1 & Exp. 2 & & Exp. 1 & Exp. 2 & & Exp. 1 & Exp. 2 \\
\hline Bokashi & $493.90 \mathrm{a}$ & $156.80 \mathrm{abc}$ & & $53.26^{\mathrm{ns}}$ & $27.58 \mathrm{~b}$ & & $68 \mathrm{c}$ & $26 \mathrm{c}$ \\
Crambe cake & $313.60 \mathrm{ab}$ & $328.80 \mathrm{a}$ & & 43.55 & $22.16 \mathrm{~b}$ & & $128 \mathrm{bc}$ & $65 \mathrm{bc}$ \\
Whey protein & $115.80 \mathrm{bc}$ & $257.00 \mathrm{ab}$ & & 85.77 & $78.37 \mathrm{a}$ & & $516 \mathrm{abc}$ & $1081 \mathrm{ab}$ \\
Cottonseed meal & $100.20 \mathrm{bc}$ & $73.20 \mathrm{c}$ & & 100.49 & $70.46 \mathrm{a}$ & & $1195 \mathrm{abc}$ & $1962 \mathrm{a}$ \\
C.S. wood chip* & $92.60 \mathrm{bc}$ & $151.60 \mathrm{abc}$ & & 171.25 & $114.11 \mathrm{a}$ & & $1297 \mathrm{ab}$ & $1691 \mathrm{a}$ \\
Control & $26.20 \mathrm{c}$ & $114.00 \mathrm{bc}$ & & 72.99 & $99.48 \mathrm{a}$ & & $2234 \mathrm{a}$ & $2365 \mathrm{a}$ \\
\hline CV (\%) & 32.72 & 29.36 & & 34.79 & 18.51 & & 47.40 & 47.90 \\
\hline
\end{tabular}

*Composted shredded wood chip (compostado de madeira de poda triturada). Average values followed by the same letter in the columns do not differ by Tukey test at $5 \%$ probability (valores médios seguidos de letras iguais nas colunas não diferem pelo teste de Tukey, $5 \%$ ). Original means transformed by $\sqrt{x+1}$ before analysis of variance (valores originais transformados em $\sqrt{x+1}$ ). ns= not significant (não significativo).

studies available in the literature, which report the potential of leftover cakes of vegetable origin for the control of nematodes (Lopes et al., 2008; Umar \& Simon, 2008; Lopes et al., 2009; Tiyagia et al., 2011; Roldi et al., 2013). In soybean, the crambe cake reduced the population of M. javanica when applied in a concentration of $31.32 \mathrm{~g}$ per pot (2 liter pots) (Tavares-Silva et al., 2012).

Cakes derived from the grinding of other brassica vegetables were also found to be effective in pathogen control. A study carried out by Mazzola et al. (2001) showed that the use of cakes made from seeds of Brown or Indian mustard (Brassica juncea), white mustard (Sinapis alba) and canola controlled Rhizoctonia solani and Pratylenchus penetrans, in apple orchard, with better results obtained when applying Brown mustard. The same result was obtained by Reardon $e t$ al. (2013), who observed that a Brown mustard cake was more effective in the control of soil nematodes than that obtained with canola (Brassica napus).

Since the cultivation of crambe is recent in Brazil, research on this plant is still limited. Thus, regarding the cake, there is no information on the substances involved in the control. However, since it is a species of the Brassicaceae family, it is possible that it includes compounds

Table 2. Fresh mass of the aerial part and roots of lettuce grown in soil infested with Meloidogyne incognita after 60 days of cultivation in two experiments under different environmental conditions (massa de parte aérea e de raizes frescas de alface cultivada em solo infestado com Meloidogyne incognita após 60 dias de cultivo em dois experimentos mantidos em diferentes condições ambientais). Umuarama, UEM, 2012.

\begin{tabular}{lccccc}
\hline \multirow{2}{*}{ Treatment } & \multicolumn{2}{c}{ Mass of the aerial part (g) } & & \multicolumn{2}{c}{ Mass of the root (g) } \\
\cline { 2 - 3 } \cline { 5 - 6 } & Exp. 1 & Exp. 2 & & Exp. 1 & Exp. 2 \\
\hline Bokashi & $26.15 \mathrm{a}$ & $26.71 \mathrm{~b}$ & & $9.23 \mathrm{a}$ & $6.88 \mathrm{~b}$ \\
Crambe cake & $32.98 \mathrm{a}$ & $68.46 \mathrm{a}$ & & $6.62 \mathrm{a}$ & $14.66 \mathrm{a}$ \\
Whey protein & $2.95 \mathrm{~b}$ & $6.47 \mathrm{c}$ & & $1.34 \mathrm{~b}$ & $3.37 \mathrm{c}$ \\
Cottonseed meal & $2.67 \mathrm{~b}$ & $3.44 \mathrm{c}$ & & $0.96 \mathrm{~b}$ & $1.11 \mathrm{c}$ \\
C.S. wood chip* & $1.61 \mathrm{~b}$ & $2.79 \mathrm{c}$ & & $0.82 \mathrm{~b}$ & $1.44 \mathrm{c}$ \\
Control & $0.66 \mathrm{~b}$ & $2.52 \mathrm{c}$ & & $0.29 \mathrm{~b}$ & $1.03 \mathrm{c}$ \\
\hline CV (\%) & 18.32 & 18.29 & 15.98 & 16.36 \\
\hline
\end{tabular}

*Composted shredded wood chip (compostado de madeira de poda triturada). Average values followed by the same letter in the columns do not differ by Tukey, $5 \%$ (valores médios seguidas de letras iguais nas colunas não diferem pelo teste de Tukey, 5\%). Original means transformed by $\sqrt{x+1}$ before analysis of variance (valores originais transformados em $\sqrt{x+1}$ ). already found in other plants of the same botanical family, such as glucosinolates, including isothiocyanates (ITC), nitriles, thiocyanates and epinitriles, whose nematicidal effect was already demonstrated (Potter et al., 1998).

In experiments 1 and 2 , whey protein reduced the number of eggs/g from roots from 76.9 to $54.3 \%$, respectively, compared to the control. This byproduct promoted $100 \%$ of mortality of secondstage juveniles of Meloidogyne exigua (Salgado \& Campos, 2003). The authors credited the obtained results to the presence of living microorganisms in the material, which modify the concentration of carbon dioxide, reducing the oxygen needed for the metabolic activity of nematodes. This product has been used for the management of other diseases such as mildew (Ferrandino \& Smith, 2007). One hypothesis to explain the positive results in the control of pathogens is the presence of lactoferrin, a natural antimicrobial agent present in the byproduct (Brown et al., 2008). However, further experiments are needed, since there are no studies in the literature that support this hypothesis.

The composted waste obtained from cottonseed and shredded wood chip did not effectively control the nematode (Table 1), nor stimulated the vegetative growth of lettuce (Table 2). There is no further information available about the action of these materials on the population of nematodes and, although composted waste of different 
origins have a negative impact on the nematodes, as those from sewage sludge, urban waste and agro-industrial processes (D'Addabbo et al., 2011), comparisons are not possible, because the products have very different origins, they surely differ in chemical, physical and microbial composition.

In both experiments, bokashi and crambe cake increased the fresh mass of the aerial part and roots of lettuce compared to the other treatments (Table 2 ). The average values obtained for the fresh mass of the aerial part in lettuce grown in soil treated with bokashi were 26.15 and $26.17 \mathrm{~g}$, in experiments 1 and 2 , respectively, while in the control treatment the values were 0.66 and $2.55 \mathrm{~g}$. The respective values for the treatment with crambe cake were 32.98 and $68.96 \mathrm{~g}$. The root mass ranged from 6.88 to $9.23 \mathrm{~g}$ and 6.62 to $14.66 \mathrm{~g}$ for the treatments with bokashi and crambe cake, respectively, while for the control treatment, the mean values ranged from 0.29 to $1.03 \mathrm{~g}$. In experiment 2 , the development of the plant treated with crambe cake was more significant than that of the plant treated with bokashi (Table 2). On the other hand, in the same way as the composted waste, the whey protein did not promote the vegetative development of the plant, when compared to the control treatment (Table 2).

The action of bokashi on the plant development had previously been observed when the addition of $20 \mathrm{~g}$ in 2 liter plant pots increased the height, dry mass of root and dry and fresh mass of aerial part of tomato (Roldi et al., 2013). According to Zandron et al. (2003), the positive effect of bokashi that increased the production of tomatoes was due to the supply of the nutrients contained in the product. Similarly, in studies with crambe cake, the vegetative parameters height, fresh and dry mass or the aerial part and fresh mass of the root of soybean increased with increase in the concentration of the cake from 10 to 50 g/pot (Tavares-Silva et al., 2012).

The results showed that the organic compounds bokashi and crambe cake effectively reduce the population of $M$. incognita and increased the development of lettuce crop under controlled conditions.

\section{REFERENCES}

AKHTAR M; MALIK A. 2000. Roles of organic soil amendments and soil organisms in the biological control of plant-parasitic nematoides: a review. Bioresource Technology 74: 35-47.

BONETI JIS; FERRAZ S. 1981. Modificação do método de Hussey \& Barker para extração de ovos de Meloidogyne exigua de raízes de cafeeiro. Fitopatologia Brasileira 6: 553.

BROWN CA; WANG B; OH JH. 2008. Antimicrobial activity of lactoferrin against foodborne pathogenic bacteria incorporated into edible chitosan film. Journal of Food Protection 71: 319-324.

CHARCHAR JM. 1995. Meloidogyne em hortaliças. In: Anais do CONGRESSO INTERNACIONAL DE NEMATOLOGIA TROPICAL, 27. Proceedings... Rio Quente: ONTA/SBN. p. 149-153.

CHARCHAR JM; VIEIRA JV; OLIVEIRA VR; MOITA AW. 2009. Cultivo e incorporação de leguminosas, gramíneas e outras plantas no controle de Meloidogyne incognita raça 1 em cenoura 'Nantes'. Nematologia Brasileira 33: 139-146.

D’ADDABBO P; PAPAJOVÁ I; SASANELLI N; RADICCI V; RENCO M. 2011. Suppression of root-knot nematodes in potting mixes amended with different composted biowaste. Helminthologia 48: 278-287.

DIAS-ARIEIRA CR; CUNHA TPL; CHIAMOLERA FM; PUERARI HH; BIELA F; SANTANA SM. 2012. Reaction of vegetables and aromatic plants to Meloidogyne javanica and $M$. incognita. Horticultura Brasileira 30: 322-326.

FAO. Food and Agriculture Organization of the United Nations. 2005. National Agricultural Statistics Service, USDA. World Fresh Lettuce Production.

FERRANDINO FJ; SMITH VL. 2007. The effect of milk-based foliar sprays on yield components of field pumpkins with powdery mildew. Crop Protection 26: 657-663.

FERREIRA S; VIEIRA VLF; GOMES LAA; MALUF WR; CARVALHO FILHO JLS. 2011. Identificação de linhagens avançadas de alface quanto à resistência a Meloidogyne javanica. Ciência e Agrotecnologia 35: 270-277.

FIORINI CVA; GOMES LAA; LIBÂNIO RA; MALUF WR; CAMPOS VP; LICURSI V; MORETTO P; SOUZA LA; FIORINI IVA. 2007. Identificação de famílias $F_{2: 3}$ de alface homozigotas resistentes aos nematoides das galhas. Horticultura Brasileira 25: 509-513.

FIORINI CVA; GOMES LAA; MALUF WR; FIORINI IVA; DUARTE RPF; LICURSI V. 2005. Avaliação de população F2 de alface quanto à resistência aos nematoides das galhas e tolerância ao florescimento precoce. Horticultura Brasileira 23: 299-302.

GONZÁLEZ M; GOMEZ E; COMESE R; QUESADA M; CONTI M. 2010. Influence of organic amendments on soil quality potential indicators in an urban horticultural system. Bioresource Technology 101: 8897-8901.

HORTIBRASIL. 2013. Alface em números. Available at: http://hortibrasil.org.br/jnw/index. php?option $=$ com_content $\&$ view $=$ article\&id $=$ 1131:alface-em-numeros\&catid=64:frutas-ehortalicas-frescas \&Itemid $=82$. Accessado em abril 10, 2014.

HUSSEY RS; BARKER KR. 1973. A comparison of methods of collecting inocula of Meloidogyne spp., including a new technique. Plant Disease Report 57: 1025-1028.

LOPES EA; FERRAZ S; DHINGRA OD; FERREIRA PA; FREITAS LG. 2009. Soil amendment with castor bean oilcake and jack bean seed powder to control Meloidogyne javanica on tomato roots. Nematologia Brasileira 33: 106-109.

LOPES EA; FERRAZ S; FREITAS LG; FERREIRA PA. 2008. Controle de Meloidogyne javanica com diferentes quantidades de torta de nim (Azadirachta indica). Revista Trópica 2: 17-21.

MAZZOLA M; GRANATSTEIN DM; ELFVING DC; MULLINIX K. 2001. Suppression of specific apple root pathogens by Brassica napus seed meal amendment regardless of glucosinolate content. Phytopathology 91: 673-679.

MORAES SRG; CAMPOS VP; POZZA EA; FONTANETTI A; CARVALHO GJ; MAXIMINIANO C. 2006. Influência de leguminosas no controle de fitonematoides no cultivo orgânico de alface americana e de repolho. Fitopatologia Brasileira 31: 188-191.

OKA Y. 2010. Mechanisms of nematode suppression by organic soil amendments. Applied Soil Ecology 44: 101-115.

PINHEIRO JB; PEREIRA RB; CARVALHO ADF; RODRIGUES CS; SUINAGA FA. 2013. Manejo de nematoides na cultura da alface. Brasília: Embrapa Hortaliças, Circular Técnica. 8p.

POTTER MJ; DAVIES K; RATHJEN AJ. 1998. Supressive impact of glucosinolates in Brassica vegetative tissues on root lesion nematode Pratylenchus neglectus. Journal of Chemical Ecology 24: 67-80.

REARDON CL; STRAUSS SL; MAZZOLA M. 2013. Changes in available nitrogen and nematode abundance in response to Brassica seed meal amendment of orchard soil. Soil Biology \& Biochemistry 57: 22-29.

ROLDI M; DIAS-ARIEIRA CR; SEVERINO JJ; SANTANA SM; DADAZIO TS; MARINI PM; MATTEI D. 2013. Use of organic amendment to control Meloidogyne incognita on tomatoes. Nematropica 43: 49-55.

SALGADO SML; CAMPOS VP. 2003. Eclosão e mortalidade de Meloidogyne exígua em extratos e em produtos naturais. Fitopatologia Brasileira 28: 166-170.

SANTANA SM; DIAS-ARIEIRA CR; BIELA F; CUNHA TPL; CHIAMOLERA FM; ROLDI M; ABE VHF. 2012. Antagonistic plants in the management of Meloidogyne incognita in sandy soil of vegetables growing areas. Nematropica 42: 287-294.

SILVA RR; GOMES LAA; MONTEIRO AB; MALUF WR; CARVALHO FILHO JLS; 
MASSAROTO JA. 2008. Linhagens de alface-crespa para o verão resistentes ao Meloidogyne javanica e ao vírus mosaicoda-alface. Pesquisa Agropecuária Brasileira 43: 1349-1356.

TAVARES-SILVA CA; FERRARESE-FILHO O; DIAS-ARIEIRA CR; ROGERIO F; VECCHI JLB; SILVA TRB; PUERARI HH; HERNANDES. 2012. Efeito da incorporação da torta de crambe sobre a população de Meloidogyne javanica. In: Anais do CONGRESSO BRASILEIRO DE NEMATOLOGIA, 30. Anais... Uberlândia: SBN. p. 128.

TIYAGIA AS; MAHAMOODA I; KHANA Z; AHMAD H. 2011. Biological control of soilpathogenic nematodes infecting mung bean using Pseudomonas fluorescens. Archives of Phytopathology and Plant Protection 44: 1770-1778.
UMAR I; SIMON SY. 2008. The effect of oil seed cakes and ploughing against plant parasitic nematodes on cowpea (Vigna unguiculata). Agricultural Journal 3: 349-352.

ZANDRON AC; RODRIGUES CDS; MACHADO CA; BRAGA MP; CHAGAS PRR. 2003. Influência do substrato no desenvolvimento da muda e o reflexo na produção de tomate T49-12. Horticultura Brasileira 21: 272-273. 